\title{
CARACTERIZACIÓN DE PAISAJES EN PEQUEÑAS Y MEDIANAS CIUDADES. PROPUESTA METODOLÓGICAAPLICADAA CONSTANTINA (SIERRA NORTE DE SEVILLA) ${ }^{1}$
}

\author{
Rocío Silva Pérez \\ Departamento de Geografía Humana. Universidad de Sevilla \\ rsilva@us.es
}

\section{RESUMEN}

Este artículo plantea una reflexión sobre los argumentos básicos a tener en cuenta en la caracterización de paisajes urbanos en ciudades pequeñas y medias. Su contenido se articula en dos partes: la primera esboza un procedimiento metodológico multiescalar que imbrica los paisajes interiores de la ciudad con los de sus entornos territoriales. La segunda aplica la metodología propuesta a una pequeña ciudad de Sierra Morena (Constantina-Sierra Norte de Sevilla) cuyos paisajes urbanos interiores poseen una gran capacidad pedagógica para interpretar la ciudad a través de sus paisajes.

Palabras clave: Paisajes urbanos, caracterización paisajística, ciudades pequeñas y medias.

\footnotetext{
ABSTRACT

This article gives a reflection on the fundamental arguments that should be borne in mind when characterising urban landscapes in small and medium-sized towns and cities. The

Fecha de recepción: marzo 2012.

Fecha de aceptación: diciembre 2012.

1 Este artículo retoma algunos planteamientos de la Acción Piloto Identificación, caracterización y cualificación de recursos paisajísticos en el entorno y el núcleo urbano de Constantina (Andalucía-España), desarrollada por un equipo de investigadores adscritos al Centro de Estudios Paisaje y Territorio (Junta de Andalucía), en el marco del Proyecto Europeo PAYS.MED.URBAN. Sus contenidos se inscriben en Proyecto de I+D del Ministerio de Economía y Competitividad del Gobierno de España sobre Paisajes Patrimoniales de la España Meridional Andaluza (CSO2012-39564-C07-07).
} 
content is divided into two parts: the first gives an overview of a multi-scale methodological procedure that dovetails towns' internal landscapes with those of their surrounding areas. The second applies the proposed methodology to a small town in the Sierra Norte Mountains (Constantina - Sierra Norte Mountains, Seville province) where the internal urban landscapes can teach us many lessons about how a city's landscapes can help us to interpret it.

Key words: urban landscapes, landscape characterisation, small and medium-sized towns and cities.

\section{ANTECEDENTES, OBJETIVOS E HIPÓTESIS DE TRABAJO}

La insistencia del Convenio Europeo del Paisaje (CEP) de que éste es una cualidad de todo territorio y que, junto a espacios excepcionales, concierne a ámbitos comunes e incluso degradados (Consejo de Europa, 2000, art. $2^{\circ}$ ) supone una concepción revolucionaria de las áreas que tienen interés como paisajes. Con anterioridad las Convenciones sobre la Vida Silvestre y el Medio Natural (Berna de 1979), sobre Patrimonio Arquitectónico (Granada de 1985) y sobre Patrimonio Arqueológico (La Valeta de 1992), precedentes inmediatos del Convenio Europeo, coadyuvaron a la asimilación entre paisajes y ámbitos de elevado valor naturalístico y/o histórico-cultural. Ello redundó en la desconsideración paisajística de espacios cotidianos y funcionales, entre los que se encuentran los ámbitos urbanos y periurbanos que tras la asunción del Convenio Europeo adquieren un inusitado interés.

En las ciudades y sus periferias inmediatas reside la mayor parte de la población; y ello las convierte en espacios particularmente visibles e interesantes desde la perspectiva del paisaje atendiendo a la definición de éste como «cualquier parte del territorio tal como es percibida por la población» ( $\operatorname{art}^{\circ} 1 \mathrm{del}$ CEP). Los paisajes urbanos y periurbanos son espacios vividos, apropiados y utilizados; y ello refuerza su consideración identitaria y su valoración patrimonial y simbólica, especialmente patente en el caso de los tejidos urbanos de las ciudades históricas (Brandís, 2008). Las áreas periurbanas han acogido, además, buena parte de la expansión urbanística reciente, con el corolario de desórdenes y fragmentaciones territoriales (Alberdi, 2002) y mermas patrimoniales y paisajísticas (Castillo, 2009); todo ello en un contexto socio-cultural en el que, cada vez en mayor medida, el paisaje es considerado como una parte esencial de la estructura territorial, como un catalizador de calidad de vida de las poblaciones y como un recurso para el desarrollo (Junta de Andalucía, 2012; Mata, 2008).

El creciente interés por los paisajes urbanos y periurbanos y la preocupación, también creciente, por los efectos devastadores del urbanismo expansivo (Rullán, 2012) contrasta con la insuficiencia teórica y metodológica para la identificación y la caracterización de tales paisajes (Zoido, 2012). La asimilación normativa tradicional entre paisajes y espacios sublimes estuvo acompañada, desde una perspectiva analítica, de un sesgo hacia el estudio de paisajes poco transformados y con amplias proyecciones panorámicas como las áreas naturales y/o los espacios agrarios (Maderuelo, 2005). El resultado ha sido cierta inopia en el estudio de los paisajes urbanos, a los que no son aplicables los patrones conceptuales y metodológicos de los sistemas naturales y/o los espacios rurales. 
En Geografía la noción de paisaje urbano tiene una amplia trayectoria que se remonta, al menos, a los orígenes académicos de la disciplina; y así se pone de manifiesto en las valiosas descripciones de algunas ciudades presentes en la obra de Humboldt (Zoido, 2012). Pero su estudio raramente ha merecido una consideración integral y autónoma y, asimilado con la morfología y la historia urbana (Capel, 2002; Quirós, 2004), a menudo se integra en obras generales donde acompaña a otros temas sin llegar a adquirir categoría sustantiva.

En resultado es, como se ha dicho, cierta insuficiencia teórica y metodológica en el análisis de los paisajes urbanos, sólo recientemente superada gracias a la sistematización conceptual y metodológica planteada por F. Zoido para los paisajes de la ciudad compacta mediterránea (Zoido, 2012). Este artículo es deudor de ese trabajo y de otros previos sobre los paisajes interiores de la ciudad (Capel, 2002; Fernández y Taxer, 2008; Ferrer, 2008; Quirós, 2004; Troitiño, 1992; Zárate, 2011) y sobre aquellos otros paisajes repetitivos, desordenados y banales cada vez más habituales en las periferias urbanas (Alberdi, 2002; Badia et al, 2010; Martín-Vivaldi y Jiménez, 1994; Pedrazzini, 2011). Pero aunque los toma como referencia se separa de ellos en diversos aspectos: 1) sitúa al paisaje en el núcleo de la investigación; 2) se centra en el estudio paisajístico de las pequeñas y medianas ciudades; y 3) aúna en un mismo trabajo el análisis de los paisajes urbanos y el de sus periferias inmediatas y remotas, esto último desde una perspectiva inter-escalar que imbrica los paisajes interiores de la ciudad con los de sus entornos territoriales.

El objetivo básico que se persigue es el de contribuir al debate sobre el estudio paisajístico de la ciudad, a través de una propuesta metodológica centrada en la determinación de las escalas de lectura de los paisajes urbanos y en la identificación de los argumentos analíticos que adquieren significación en cada escala. A ese objetivo general se suman otros más específicos relacionados con el ensayo de la metodología propuesta en una pequeña ciudad (Constantina- Sevilla) cuya inserción en el marco territorial de Sierra Morena y la posterior declaración del Parque Natural de la Sierra Norte de Sevilla constituyen dos elementos clave en la gestación y posterior dinámica de sus paisajes urbanos. Constantina es, además, una ciudad muy particular, pues aunque no alcanza el rango demográfico urbano -o lo ha perdido debido a la emigración y el despoblamiento- ha desempeñado y desempeña funciones típicamente urbanas y ello se trasluce en cierta complejidad de sus paisajes urbanos interiores.

Se parte de la siguiente hipótesis de trabajo: los paisajes urbanos interiores de las pequeñas y medianas ciudades se han gestado de manera simbiótica con los de sus entornos agrorurales. Ello desaconseja la separación analítica entre tales paisajes e impele a la búsqueda del diálogo, siempre complejo, entre lo urbano, lo rural y lo territorial. Se trata, esta última, de una premisa muy en consonancia con los planteamientos de la Estrategia Europea 2020 (Comisión Europea, 2010), y, en particular, con su consideración de las áreas rurales y urbanas como espacios complementarios y sinérgicos y no como ámbitos dicotómicos como se había considerado hasta ahora.

Aunque se comparte la idea de que los paisajes son, sobre todo, miradas y representaciones (Cosgrove, 2002), el análisis se refiere sólo a la dimensión objetiva u objetivable de los paisajes urbanos y deja para otro momento el estudio de su dimensión subjetiva y cualificadora, encaminada a la asignación de valores y significados (Scazzosi, 2006) y a la definición de «objetivos de calidad paisajística» ( $\operatorname{art}^{\circ} 1$ del CEP). 


\section{PRODEDIMIENTO METODOLÓGICO PARA LA CARACTERIZACIÓN DEL PAISAJE EN CIU- DADES PEQUEÑAS Y MEDIAS}

El conocimiento científico del paisaje no ha abordado de manera suficiente las relaciones entre ciudad y paisaje y se carece de un marco epistemológico sobre los aspectos básicos a considerar en el estudio de los paisajes urbanos (Zoido, 2012). El Convenio Europeo del Paisaje ofrece, en aras a la superación de ese vacío, un entendimiento sencillo e integrador que contiene, además, una visión dinámica y relacional que ayuda a superar el carácter polisémico, ambiguo e incluso confuso que a menudo se atribuye al paisaje.

Su definición sistémica de los paisajes como el resultado de la acción en los territorios de factores naturales y humanos y sus interrelaciones ( ${\operatorname{~} r t^{\circ}}^{\circ}$ del CEP) impele a la consideración de los componentes (y atributos) que estructuran los paisajes urbanos y de los procesos que explican sus funcionamientos (Pino, Rodá y Guirado, 2006). Y en tanto que sistemas abiertos, tales estructuras y bases funcionales han de ser, además, contextualizadas en un marco territorial más extenso. Dos aspectos adquieren un significado especial en el estudio de los paisajes urbanos en pequeñas y medianas ciudades: 1) La determinación de sus escalas de análisis; y 2) La concreción de los elementos (y atributos) que tienen significación en cada escala.

En lo que a la escala se refiere, hay que tener en cuenta que los paisajes de las pequeñas y medianas ciudades y sus interfaces urbano-rurales pertenecen al mundo de la pequeñez y lo cualitativo; por lo que sólo son perceptibles a escalas amplias y de detalle. El Atlas de los paisajes de España no los identifica entre sus asociaciones, tipos y/o unidades de paisaje (Mata y Sanz, 2003); y tampoco aparecen dibujados entre las categorías, áreas y ámbitos paisajísticos del Mapa de Paisajes de Andalucía (Consejería de Obras Públicas y Transporte y Consejería de Medio Ambiente, 2005). En los atlas y mapas de paisaje lo urbano se circunscribe a las manchas que proyectan las grandes urbes y sus entornos metropolitanos. En cambio, las ciudades pequeñas y medias raramente se dibujan, ya que requieren una escala mayor de trabajo, más específicamente urbana aunque no sólo centrada en la ciudad.

Según la hipótesis que aquí se plantea el estudio paisajístico de las pequeñas y medianas ciudades requiere una aproximación multiescalar, que recale en la lectura de los paisajes en los que se integra la ciudad y en la interpretación de la ciudad a través de sus paisajes. Aquí se propone ésta a tres niveles: 1) Un primer nivel representado por el contexto territorial, considerando el territorio en un sentido amplio como soporte físico-natural, espacio geográfico-relacional y contexto económico-cultural; 2) Un segundo nivel correspondiente a las periferias inmediatas de las ciudades o escala de interfaces urbano-rurales; y 3) El tercer nivel sería la escala urbana propiamente dicha o ciudad compacta mediterránea.

\section{El contexto territorial como primer referente escalar en el estudio de los paisajes urbanos}

La escala territorial es imprescindible para aprehender el sentido general de un asentamiento o núcleo urbano. La situación geográfica, las funciones productivas y la organización social del espacio son algunos de los atributos que encuentran explicación a este nivel. El concepto de situación resulta muy útil para su estudio, entendida ésta como el encuadre de la ciudad en un contexto territorial más extenso, en las diferentes y complementarias acep- 
ciones de territorio como ente físico-natural -unidades fisiográficas, rasgos climáticos, redes hidrográficas y áreas de vegetación-; como espacio geográfico-relacional -integrado por nodos (ciudades), redes (vías de comunicación) y superficies (usos del suelo); como entidad socio-cultural y económica -que incluye las costumbres y las herencias compartidas, los modos de utilización del espacio y las dinámicas socio-económicas-; y como marco institucional -en una visión del territorio como receptor de normas y leyes-.

El estudio de la situación -en sus diferentes y complementarias acepciones- no resulta en absoluto baladí para la comprensión de los paisajes urbanos. El medio físico-natural constituye el telón de fondo que cobija a las ciudades y que determina los modelos de utilización del espacio y la propia cultura y economía urbana, reflejada, a su vez, en el paisaje urbano interior y, en particular, en las tipologías edificatorias y en los rasgos básicos de los espacios libres públicos. La visión del territorio en términos relacionales (como nodos y redes) remite a la accesibilidad y frecuentación de los paisajes y al número de sus potenciales observadores; dos aspectos, estos últimos, que son esenciales en el entendimiento perceptivo del paisaje y en la consideración de éste como un recurso competitivo básico para el desarrollo de los territorios (Cortina, 2008).

Los argumentos analíticos de los paisajes urbanos desde esta escala territorial de análisis son, como se ha dicho, el contexto físico-natural, geográfico y socio-económico en el que se inserta y por el que se explica la ciudad.

\section{Las periferias urbanas como escala intermedia de aproximación analítica}

La segunda escala para el análisis paisajístico de las pequeñas y medianas ciudades es la de interfaces urbano-rurales, que está muy condicionada por el emplazamiento. Son éstos paisajes híbridos de campo y cuidad, muy vulnerables frente a las expansiones urbanas y sus secuelas de fragmentaciones, deterioros y desapariciones de tramas parcelarias, caminos rurales e hitos paisajísticos significativos. Ello explica que la prestigiosa metodología británica Landscape Character Assessment (LCA) les confiera una importancia creciente en aras a la consecución de un crecimiento urbano ordenado y acorde con las características paisajísticas de cada localidad (Countryside Agency and Scottish Natural Heritage, 2002). La LCA propone como argumentos de análisis de estos contornos urbano-rurales el estudio de las conexiones formales entre la ciudad y elementos naturales como el relieve o los cursos fluviales; sus relaciones funcionales con el suelo rústico (ruedos, huertos, ejidos); el grado de definición y/o acabado del límite urbano; y el estudio de las edificaciones tradicionales extramuros y sus integraciones en los paisajes (Matías, 2011).

Otro componente esencial de esta escala de interfaces urbano-rural son las vías de acceso a las poblaciones y sus prolongaciones en travesías urbanas (Sánchez del Árbol y Medina Barbero 2008). Tanto unas como otras actúan como entradas y escaparates públicos de las ciudades y condicionan las primeras percepciones que se tienen de ellas; a lo que se suma la singularidad paisajística de algunos de sus trazados y el valor que les confiere su condición de vías históricas, particularmente en los accesos y travesías integradas en itinerarios culturales y/o rutas turísticas (Carrera, 2006; Venegas y Rodríguez, 2002). Pero pese a su innegable interés paisajístico, es muy común que los accesos urbanos proyecten una imagen desordenada y banal, poco adecuada al valor patrimonial de las ciudades a las que sirven; lo 
que obviamente redunda en un desaprovechamiento de sus potencialidades para la lectura de los paisajes urbanos y para el desarrollo socioeconómico de las poblaciones. En términos analíticos los accesos a las localidades admiten cierta jerarquización en razón de su uso y frecuentación; o atendiendo a su carácter actual, pasado (caminos históricos) o futuro (variantes en proyecto y/o previstas). Además de a las condiciones técnicas y funcionales del viario (estado del firme y elementos de seguridad y confort), su consideración paisajística debe atender a aspectos tales como la integración visual de los trazados -en sus consecutivos planos de visión- y el adecuado tratamiento de los laterales -en cuanto a dotaciones de miradores y otros equipamientos paisajísticos, mobiliario urbano, re-vegetación y señalética, etc.- (Sánchez y Medina, 2008).

Desde las vías de acceso y cuando el emplazamiento y las cuencas visuales que proyectan la ciudad lo permiten se obtienen las imágenes de conjunto de las poblaciones, muy importantes en la conformación de su carácter paisajístico y que son reconocidas por la sociedad como un componente identitario (Zárate 2007 y 2011). Las imágenes de conjunto proyectan, además, un primer y a menudo certero retrato de las escenas urbanas interiores e invitan -o disuaden- a la visita de las ciudades. Su cuidado es por tanto esencial para la activación de las potencialidades del paisaje como un recurso económico básico. Pese a ello, y a pesar también de que han sido consideradas como un recurso territorial de primer orden (Ocaña y Gómez, 2003), salvo contadas y significativas excepciones (Pardo García, 2010) las imágenes de conjunto no suelen recibir una particular atención y ello las convierte en un recurso paisajístico sumamente frágil y desaprovechado.

Los argumentos esenciales de los paisajes urbanos vistos desde esta escala de interfaces urbano-rurales son los bordes de las ciudades, las áreas de interés paisajístico de sus inmediaciones (huertas tradicionales, ruedos, ejidos) y las vías de acceso a las poblaciones, con una especial insistencia en este último caso en aquéllas vías desde las que se obtienen imágenes significativas o de conjunto.

\section{Los paisajes interiores de la ciudad como escala analítica básica}

La escala básica para el análisis paisajístico de las ciudades pequeñas y medias es, como es obvio, aquella propiamente urbana representada por la ciudad compacta mediterránea y sus áreas paisajísticas interiores. Ésta es en sí misma una escala compleja, que tiene por infraestructura elemental el entramado urbano y cuya quintaesencia paisajística son las redes de espacios libres públicos (Batlle, 2006; García, 2011; Zoido, 2012).

La identificación de los paisajes urbanos con los espacios libres públicos tiene de una dilatada tradición en el mundo del arte; concretamente, en las pinturas del settecento italiano de escenas urbanas de Venecia (de Canaletto, Guardi o Belloto) o de Roma (de Van Vitel). Con ellas se inaugura un género pictórico (las vedute) que ha llegado con fuerza a la actualidad en obras como Gran Vía de Madrid de Antonio López. Pero independientemente de su valor estético y/o simbólico y de que hayan sido objeto de recreaciones literarias, fotográficas o pictóricas, los espacios públicos son elementos cruciales en el estudio de la ciudad, que articulan la trama urbana e imprimen el carácter de sus paisajes.

El estudio de los espacios públicos impregna en la actualidad el estudio de la ciudad y es abordado, cada vez en mayor medida, desde los postulados del Convenio Europeo del Paisaje 
para el que las redes de espacios públicos son un compendio a escala urbana. Como resultados formales de la evolución y superposición de distintos modelos de ciudad los espacios públicos sintetizan la historia urbana (García, 2011) y encierran, en sí mismos, un elevado valor patrimonial. Como ámbitos de sociabilidad en ellos se desenvuelve la vida ciudadana en sus diversas manifestaciones culturales (carnavales, procesiones, cabalgatas), lúdicorecreativas (encuentros y juegos) y reivindicativas (protestas y manifestaciones). Los espacios públicos condensan, en suma, las aspiraciones, los miedos y los anhelos de la población respecto a sus paisajes y recogen las esencias formales, funcionales, históricas, perceptivas y vivenciales que el Convenio Europeo les atribuye.

El desempeño de esa función básica de ámbitos de convivencia tiene que ver con determinados atributos, entre los que ocupan un papel destacado los equilibrios distributivos de los espacios libres públicos en la trama urbana y sus ubicaciones respecto a las viviendas (García, 2011; Martínez Sarandeses, 2002), su diversidad funcional y atractivo paisajístico y la presencia en ellos de elementos de estabilidad (histórica y perceptiva) que refuercen su identidad y actúen como guías armonizadoras de las integraciones paisajísticas de elementos sobrepuestos en sucesivos momentos (Ferrer Aixala, 2008). Todo ello remite, a su vez, a la confortabilidad, la habitabilidad y la frecuentación como valores esenciales de los espacios libres públicos, evaluables a través de atributos tales como la distribución o proporción entre espacios libres y construidos existente en cada sector urbano; las tipologías predominantes; sus dimensiones y perfiles transversales; la densidad y la escala de sus construcciones perimetrales; las cualidades estéticas de los frentes de parcela (fachadas y soportales); las jerarquías del viario; los hitos paisajísticos más significativos y/o los puntos focales o de encuentro; el valor paisajístico de la vegetación, la iluminación y el mobiliario urbano; y las vistas o secuencias visuales que proyectan.

Los argumentos esenciales del análisis paisajístico del interior de la ciudad se resumen en las diferentes piezas (o barrios) que articulan su trama urbana y, dentro de cada unidad, en los rasgos básicos de sus redes de espacios libres públicos.

\section{EJEMPLICACIÓN DE LA PROPUESTA METODOLÓGICA EN LA CIUDAD DE CONSTANTINA (SIERRA NORTE DE SEVILLA)}

\section{El contexto territorial y su influencia en los paisajes urbanos}

El contexto territorial de Constantina ofrece un buen ejemplo para el análisis de las claves paisajísticas relacionadas con la situación de la ciudad en el paisaje. Su marco físico-natural es Sierra Morena, una vieja y media montaña mediterránea que en términos estructurales no es más que el escalón meridional de la meseta española fracturado y rejuvenecido por el movimiento alpino. De ello resulta una secuenciación de unidades organizadas siguiendo la dirección armonicana NW-SE, en cuyos interfluvios se instalan ríos estrechos y encajados que salvan elevadas pendientes en cortos recorridos y que, a modo de bisturís, inciden sobre el terreno dando lugar a un paisaje que parece esculpido en bajorrelieve. El núcleo urbano de Constantina se sitúa precisamente en uno de esos valles angostos (el Valle de la Osa), jalonando las orillas de un rio de tanta relevancia urbana que es nominado con tres topónimos diferentes en su transcurso por la ciudad (Rihuelo, río Allende y río de la Villa). Tal circuns- 

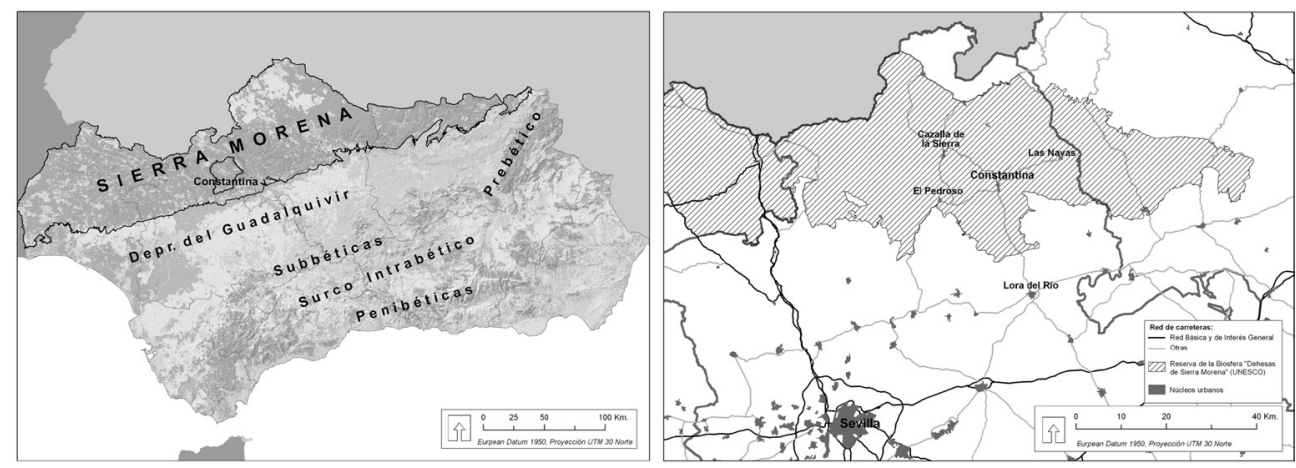

tancia físico-natural dota a sus escenas urbanas interiores y los paisajes de sus periferias inmediatas de dos recursos específicos en el contexto territorial de Sierra Morena: el relieve y el agua.

El sustrato geológico de Sierra Morena es de rocas duras e impermeables (pizarras, granitos, cuarcitas), con algunas inserciones calizas y suelos ricos en arcillas y limos, situados éstos últimos en los fondos de valle (Ojeda y Silva, 2002). La dureza del roquedo da lugar a suelos raquíticos y pobres. En dicho contexto de valles encajados, de topografía difícil y enmarcados en una sierra impermeable, seca y pardusca, el agua y la caliza son fuentes esenciales de riqueza y de vida. Así se refleja en la localización del núcleo urbano de Constantina sobre una de las tres unidades hidrogeológicas existentes en la Sierra Norte (el acuífero de Cazalla-Constantina), donde la presencia de materiales calizos permite la disponibilidad de aguas subálveas para el abastecimiento urbano.

La biogeografía otorga a Sierra Morena su propio apelativo que alude a su vegetación densa y oscura, constituida por una diversidad de comunidades cuyo estado climácico estaría representado por bosques de encinas y alcornoque, aclarados y convertidos en dehesas y enriquecidos conforme aumenta la altitud y la humedad con especies de talante oceánico como robles, quejidos o castaños. En Constantina, dehesas y áreas boscosas ocupan más de las tres cuartas partes de la superficie municipal; y también se dispone de manchas de matorral noble herederas del bosque mediterráneo primitivo en el paraje de Monte Negrillo; rodales de robles en El Robledo; y numerosas fincas de castaños localizadas en las zonas más húmedas. Algunos de estos espacios conforman Áreas de Interés Paisajístico de los alrededores de la ciudad o caminos históricos muy frecuentados como el camino de Los Castañares que forma parte de la red de senderos de uso público del Parque Natural (véase el epígrafe 5).

Pero en un contexto mediterráneo y de vieja civilización como Sierra Morena aquellas formaciones vegetales raramente se mantienen en su estado originario. De hecho los bosques de castaño han sido aquí introducidos por el hombre y el bosque primitivo ha sido aclarado y reconvertido en dehesas agroganaderas. Aunque más exiguas en extensión, también adquieren una especial significación las superficies de cultivo, generalmente situadas en torno a los núcleos urbanos en formas de aureolas concéntricas de pequeños regadíos, áreas cerealistas y 
olivares, seguidos de dehesas y bosques de uso común. La configuración alargada del núcleo urbano de Constantina -debida a su emplazamiento encajado en el fondo de un valle-rompe aquella característica configuración radio-concéntrica y sus paisajes de interfaces urbanorurales se organizan en bandas alargadas en torno al núcleo urbano; y ello constituye otra de sus particularidades paisajísticas.

Desde un punto de vista geográfico Sierra Morena es un espacio netamente rural en cuanto a sus usos dominantes, con una presencia significativa de núcleos de población excéntricamente situados respecto a los principales ejes viarios que surcan Andalucía. La ciudad de Constantina escapa, no obstante, al aislamiento ancestral de Sierra Morena e históricamente ha estado bien comunicada con la ciudad de Sevilla para la que ha cumplido un papel de avanzadilla defensiva (Collantes, 2011). Las mejoras introducidas en las vías de comunicación la sitúan hoy a menos de una hora en distancia-tiempo de la capital de regional. Junto con la dotación de nuevos equipamientos y servicios públicos (como el hospital comarcal o la Oficina Comarcal Agraria de los pueblos de la Sierra Norte) ello refuerza su papel de intermediación respecto a otras localidades del entorno y afianza su condición de ciudad, independientemente de su rango poblacional: poco más de 6.500 habitantes, aunque a mediados del siglo pasado se acercaba a los 14.500. Desde una perspectiva paisajística dicha condición urbana se trasluce en cierta complejidad de los paisajes urbanos interiores (véase el apartado 6).

En términos económicos y socio-culturales Sierra Morena es una zona de antiguos poblamientos y prósperas economías tradicionales, quebradas por la masividad y la tecnocracia desarrollista -y sus secuelas de abandonos, despoblaciones y deterioros patrimoniales y paisajísticos-, luego redescubiertas por el ambientalismo y la actual sociedad del ocio (Silva y Ojeda, 2001). Unos procesos, todos ellos, que están igualmente bien reflejados en la dinámica demográfica y paisajística de Constantina. Su posición estratégica de antiguo paso obligado entre el Valle del Guadalquivir y la meseta y entre las ciudades de Córdoba y Mérida explica su antigua e intensa ocupación humana (Collantes, 2011): más de 1.300 vecinos en el siglo XVIII según la información contenida en el Diccionario Geográfico de Tomas López, incrementadas a 6.983 almas a mediados del siglo XIX de acuerdo con Diccionario de Madoz. El Expediente de Riqueza Territorial de 1816 reincide en esa potencia urbana expresada en un total 1055 casas, 978 de ellas de propiedad particular y 77 pertenecientes a comunidades religiosas (citado por Linares y Tejedor, 2001).

Internamente el tejido edificatorio de Constantina ofrece un buen ejemplo del despegue socio-económico experimentado por Sierra Morena de finales del XIX (asociado al auge de la industria y la minería y al trazado del ferrocarril) y de los efectos urbanos de los procesos desamortizadores. Exponentes paisajísticos de la efervescencia industrial del XIX, en las cercanías de la localidad, son los altos hornos de El Pedroso y las minas a cielo abierto del Cerro del Hierro hoy declaradas Monumento Natural. Otras muestras de aquel auge industrial, en las inmediaciones de la ciudad, son los numerosos molinos y lagares y varias fábricas de hielo. En el tejido urbano interior el florecimiento industrial se tradujo en la aparición de bodegas y tenerías relacionadas con el cuidado de la piel y en la densificación del caserío: un total de 1.427 casas repartidas en 73 calles, junto a un nutrido conjunto de edificaciones industriales, entre molinos harineros (un total de 14), de aceite (9), lagares (hasta 780), 1 fábrica de curtidos, 1 fábrica de jabón y varias de aguardiente (citado por Linares y Tejedor, 2001). 
Y como en otras muchas ciudades españolas las subastas desamortizadoras se tradujeron en Constantina en una importante remodelación urbana, con la apertura de calles y plazas sobre áreas de antiguos conventos. Aquellos procesos decimonónicos alentaron, además, la llegada de burgueses que, ávidos de exhibir su recién adquirida riqueza, contribuyeron al remozamiento urbano con la construcción de palacetes y edificios de estética modernista como los existentes en torno a la Plaza de Santa Ana.

La quiebra de aquellas prósperas economías -y el deterioro de los paisajes- se inicia a mediados de los sesenta del siglo pasado en un marco desarrollista y productivista, poco respetuoso con dos de los principios básicos de estas sierras: la diversidad y la pequeñez. El resultado fue una fuerte embestida migratoria y sus secuelas de envejecimientos, retrocesos de la natalidad y reincidentes despoblamientos; unos procesos, todos ellos, especialmente virulentos en la ciudad de Constantina, que en 1950 contaba con 14.461 habitantes, reducidos a poco más 10.700 en 1970, a 8.123 en 1981 y a 6.586 en 2011. El éxodo rural es selectivo y afectó, sobre todo, a los pequeños propietarios de los aledaños de los pueblos; y, en el caso nos ocupa, se tradujo en el abandono de los regadíos históricos del paraje de la Yedra. En el tejido urbano interior la sangría demográfica redundó en ruinas de viviendas y edificios significativos, hasta alcanzar un total de 531 viviendas vacías en el interior de la ciudad según estimaciones del PGOU.

A partir de finales de los años ochenta del siglo pasado asistimos un nuevo viraje socioeconómico de Sierra Morena, relacionado con la emergencia del naturalismo, el reconocimiento del valor histórico-cultual de sus pueblos y su conversión en un espacio para el ocio y el disfrute. El marchamo institucional ha tenido un papel crucial en todo ello, con la declaración de Parques Naturales (como el de la Sierra Norte de Sevilla), de Monumentos Naturales (como las Cascadas del Huéznar y el Cerro del Hierro, situados ambos en las proximidades de Constantina), de la Reserva de la Biosfera Dehesas de Sierra Morena, de Zonas Especiales de Protección de Aves, de Zonas Especiales de Conservación, etc. A ello se suma, desde la perspectiva del patrimonio histórico-cultural, la declaración de tres Conjuntos Históricos de la Sierra Morena sevillana (Constantina, Cazalla de la Sierra y Guadalcanal) Bienes de Interés cultural (BIC), además de otras muchas catalogaciones patrimoniales de BIC como las del castillo de Constantina, la iglesia de la Encarnación y la ermita de la Yedra.

Tales virajes socio-económicos e institucionales parecen estar contribuyendo a cierta recuperación socio-demográfica de Sierra Morena, que ha dejado de perder población al ritmo en que lo venía haciendo; lo que cabe interpretarse como una mejora respecto a la situación inmediatamente anterior. También ha propiciado la apertura de nuevas empresas relacionadas con el auge de la hostelería y el turismo rural para las que el cuidado de los paisajes constituye un marchamo competitivo básico. En términos paisajísticos los resultados de todo ello son ciertamente ambivalentes. En los paisajes interiores de la ciudad se combinan actuaciones contradictorias de arreglos de calles, rehabilitaciones de edificios y dotaciones de equipamientos y servicios públicos; aunque no se consigue atajar la aceleración del estado ruinoso del caserío. Junto a ello se aprecia un progresivo afeamiento y pérdida de calidad de espacios públicos muy emblemáticos como la plaza de Santa Ana, recientemente desmontada de vegetación y reconstruida bajo parámetros paisajísticos menos amables. Las nuevas dinámicas socio-institucionales también se dejan sentir en los paisajes de los aledaños de las ciudades, sometidos a nuevas presiones urbanizadoras y/o restaurados con materiales 
industriales y banalizadores como está ocurriendo en Constantina en el área de las antiguas huertas de la Yedra.

\section{La escala de interfaces urbano-rurales. Claves paisajísticas relacionadas con el emplaza- miento}

La segunda escala para el análisis de los paisajes urbanos es, como se ha dicho, la de los bordes campo-ciudad cuyos argumentos analíticos básicos son las áreas de interés paisajístico de las periferias urbanas, los accesos a las poblaciones y las imágenes de conjunto que desde ellos se obtienen. Constantina ofrece, a este respecto, una interesante y particular simbiosis entre emplazamiento defensivo e historia y morfología urbana que se trasluce tanto en sus paisajes urbanos interiores (véase el epígrafe 6) como en los de sus contornos urbanorurales. La morfología del emplazamiento encajado confiere una gran singularidad a los paisajes de interfaces urbano-rurales, singularizados por el relieve y el curso del río cuyas trazas determinan la disposición de los paisajes peri-agrarios y peri-forestales y la de los propios ejes viarios e imágenes de conjunto más significativas de la localidad (figura 2).

La linealidad del emplazamiento encajado repercute, como se ha dicho, en la configuración alargada en bandas altimétricas de los paisajes de interfaces urbano-rurales: huertas

Figura 2

ELEMENTOS FUNDAMENTALES DE LOS PAISAJES DE INTERFACES URBANO-RURALES

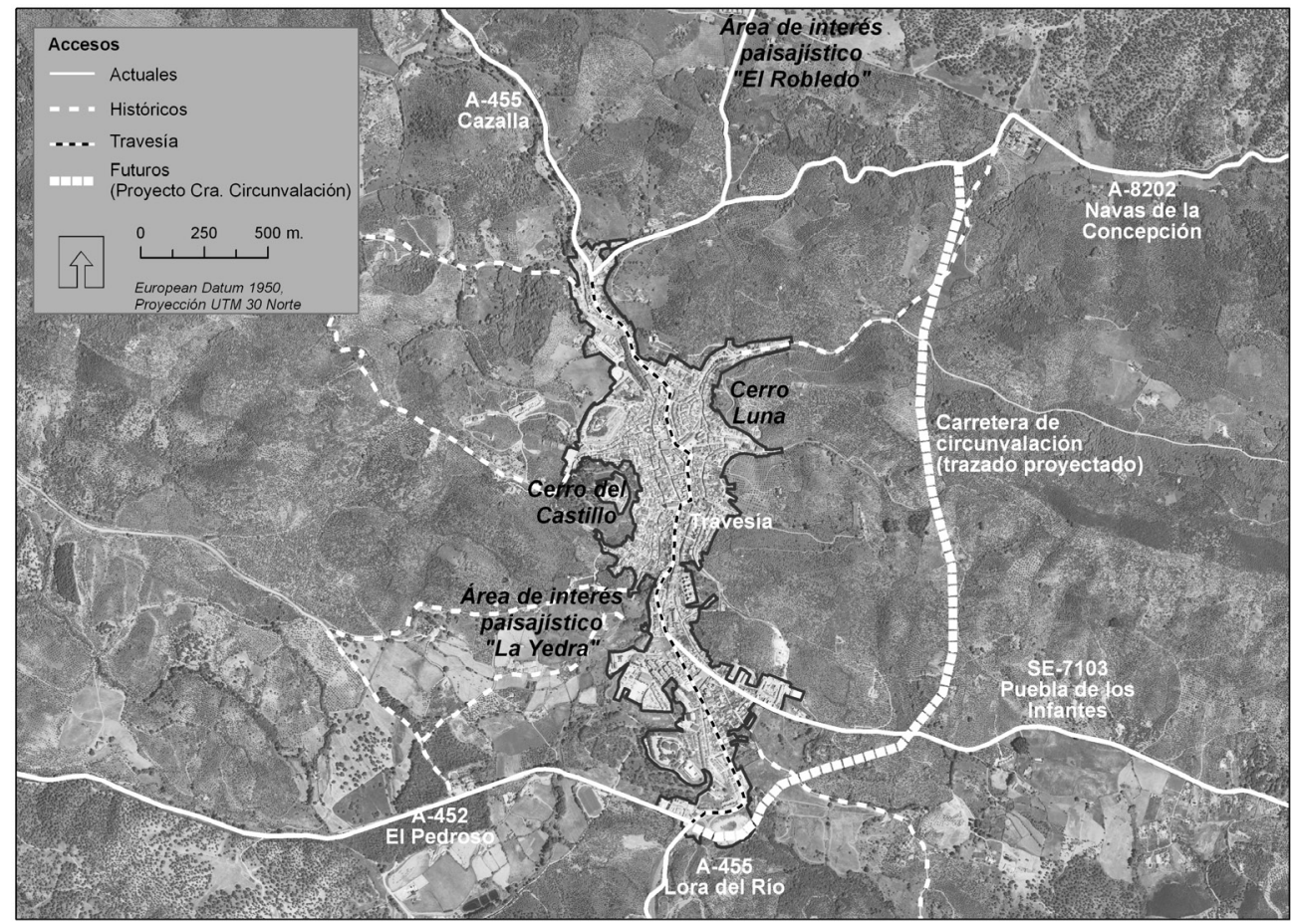


en las cotas más bajas, ocupaciones urbanas de las laderas y el fondo del valle y colinas olivareras como cierre de escena. Aunque se trata, en su mayor parte, de paisajes con grandes valores escénicos no todos ellos conforman áreas de interés paisajístico; una categoría sólo circunscrita a ciertos enclaves con una gran potencia identitaria y/o un elevado valor simbólico como las huertas de la Yedra y el Paraje del Robledo. Ambos compendian a modo de herencia histórica las bases funcionales originarias de una ciudad, que primero fue agrícola y hortelana (como lo ejemplifica el paisaje peri-agrario de la Yedra) y luego ganadera y mesteña (reflejada en el paisaje peri-forestal del Robledo).

La Yedra y sus huertas explican el primer emplazamiento urbano de Constantina: el actual barrio de la Morería. Por ellas discurría el principal camino histórico de acceso a la población (el Camino Real). Debieron constituir, por tanto, un área históricamente muy frecuentada, cargada de simbolismo y fuerza identitaria; y así lo atestigua la presencia de una potente iglesia que se mantuvo en culto hasta mediados del siglo XX (la ermita de la Yedra) y de hitos tan significativos como son los antiguos humilladeros (Valor et al., 2006). Durante el siglo XIX la Yedra pasaría a albergar muchas de las instalaciones prototípicas del auge industrial de Constantina (molinos, batanes, tenerías, bodegas, etc.), algunas de las cuales aún persisten aunque en estado ruinoso al igual que la propia ermita. El éxodo rural y la emigración de la segunda mitad del siglo XX propiciaron el abandono y la degradación paisajística de este paraje históricamente muy reconocido y valorado, que quedaría convertido en una trasera urbana. Aun así, sus paisajes atesoran grandes valores relacionados con la plasticidad de las micro-teselas de sus pequeñas propiedades, con las cercas de piedra de cierre de sus parcelas y con las urdimbres de sus caminos rurales. El reconocimiento de tales valores no ha conseguido invertir la decadencia paisajística de la Yedra, elegida por el actual PGOU (y antes por las Normas Subsidiarias) como área de expansión de la ciudad y sobre las que se están ejecutando pavimentaciones de antiguos caminos con materiales industriales desacordes con las texturas paisajísticas tradicionales.

El segundo ámbito de interés paisajístico de las inmediaciones de Constantina, algo más alejado del núcleo urbano, es el paraje peri-forestal del Robledo que ocupa un antiguo terreno comunal situado en las proximidades de la Cañada Real del Robledo y que debe su topónimo a las manchas de robles melojos allí presentes. Se trata de un espacio relativamente agreste y con elevados valores escénicos desde el que se obtienen amplias vistas sobre la sierra; pero su relevancia paisajística radica, sobre todo, en que constituye un lugar simbólico e identitario marcado por la presencia de la ermita de la patrona de Constantina (la virgen del Robledo). Ello lo convierte en un paraje muy frecuentado; particularmente durante el verano, coincidiendo con la celebración de distintos actos religiosos que tienen como desenlace el traslado de la virgen a la iglesia parroquial de la Encarnación y su retorno a la ermita en el último fin de semana de septiembre mediante una concurrida romería.

Otro componente analítico básico de estos paisajes de interfaces urbano-rurales lo conforman, como antes se dijo, las vías de acceso a las poblaciones cuyos trazados condicionan las sus imágenes de conjunto que desde ellas se obtienen. En Constantina la disposición alargada, debida al relieve, encuentra un fiel reflejo en el trazado de sus principales ejes viarios, tanto históricos como actuales o futuros, que en ella raramente coinciden (véase la figura 2). Entre las vías históricas destaca el camino de los Molinos, también conocido como «Callejón de la Yedra», que debió ser el principal acceso a la población adentrándose en ésta 
por el Suroeste después de atravesar las huertas de la Yedra bajo el control visual del Castillo. Otros caminos históricos igualmente relevantes son el de la Jurdana (en la parte occidental del núcleo urbano) y los caminos del Pocito y el Cementerio (en su sector oriental). Se trata, en su mayor parte, de vías en desuso, pero que a pesar de su degradación y abandono conservan grandes valores como los empedrados de algunas de sus calzadas, los muros de piedra de cierre de las parcelas y la plasticidad y el colorido de los paisajes por los que transitan.

La entrada más frecuentada entre las vías actuales es la A-455 (o carretera de Lora del Río) que se adentra en el núcleo urbano por el Sur y lo atraviesa hasta conectar con la carretera de Cazalla (que es la misma A-455). Ello origina una gran congestión y caos circulatorio en las vías urbanas principales y redunda en una falta de confortabilidad de sus espacios libres públicos. Otra carretera relativamente frecuentada es la A-452 (o carretera de El Pedroso), que conecta con la entrada histórica de Los Molinos y se adentra en Constantina por el SO. Menos frecuentadas son la SE-7103 (o carretera de Puebla de los Infantes) y la A-8202 (que se dirige a Las Navas de la Concepción). En lo que a condiciones técnicas se refiere, todas las carreteras señaladas combinan secciones de tramos rectos con trazados sinuosos, como por otra parte es habitual en las carreteras de sierra. En términos paisajísticos son carreteras bien integradas en sus respectivos entornos y transitan por paisajes muy representativos y conspicuos de Sierra Morena entre los que se cuentan distintos modelos fisonómicos de dehesas (omnipresentes en este territorio), afloramientos graníticos (en la carretera de Lora), olivares serranos (especialmente destacables en la carretera de Puebla de los Infantes) y pequeños regadíos periurbanos (visibles en la carretera de Las Navas). Se trata, en consecuencia, de carreteras con elevados valores y potencialidades escénicas, actualmente desaprovechadas debido a la ausencia de equipamientos paisajísticos, miradores y señalética alusiva a los paisajes en todos sus tramos.

En relación a los accesos futuros, con el objeto de dar solución los problemas ocasionados por la travesía urbana de la A-455 se tiene previsto construir una variante que circunvalará la ciudad por su sector Este (véase la figura 2). Es éste sin duda uno de los proyectos con más implicaciones paisajísticas y capacidad transformadora del núcleo urbano y el entorno de Constantina en el corto-medio plazo, que ocasionará importantes alteraciones en los paisajes por los que transite, abrirá nuevas perspectivas visuales sobre la población y aumentará el protagonismo funcional y paisajístico de las colinas orientales del núcleo. Pero sobre todo, liberará un eje de oportunidad Norte-Sur en el centro de la ciudad que requiere una particular gestión y ordenación paisajística a la que no se está prestando la suficiente atención.

En lo que a vistas urbanas exteriores se refiere, la ciudad de Constantina se resguarda, como se ha dicho, entre el relieve y no adquiere una posición prominente. Ello hace que su proyección visual sea limitada y las imágenes de conjunto más transversales que longitudinales. La única imagen integral y unitaria que se tiene de la localidad corresponde a una fotografía histórica del archivo municipal, tomada desde un camino secundario, hoy poco frecuentado. La silueta urbana actual se lee a partir de imágenes cercanas, captadas desde los dos principales oteros que cierran la ciudad por sus flancos este y oeste (Cerro del Castillo y Cerro Luna). Desde ellos se obtiene una imagen muy nítida de la ciudad que deja entrever el callejero urbano, la textura de grano fino del caserío, el color blanco de las fachadas y el rojizo de la teja árabe y las siluetas del Castillo y la Iglesia de la Concepción como hitos más significativos y destacados. Tales imágenes unitarias sobresalen, además, por la nitidez de 
los bordes urbanos, la claridad y las armonías compositivas de los límites campo-ciudad y la adaptación a la topografía de las distintas unidades de paisajes urbanos y periurbanos que la componen. Como contrapartida, los desniveles topográficos acrecientan la visibilidad y, con ello, la fragilidad de tales paisajes ante la incorporación de elementos extraños e impactantes como los bidones de agua que coronan las techumbres y los tejados de uralitas sustitutorios de la tradicional teja árabe, y/o ante actuaciones poco afortunadas en cuanto a volúmenes, colores y/o tipologías extrañas y banalizadoras.

\section{Los paisajes urbanos interiores. La interpretación de la ciudad a partir de sus paisajes}

El núcleo central del análisis paisajístico de la ciudad son los paisajes urbanos propiamente dichos, integrados por las distintas piezas que componen el tejido urbano y sus respectivas redes de espacios libres públicos e hitos paisajísticos significativos. En el caso de Constantina el emplazamiento encajado de la localidad encuentra un fiel reflejo en la historia y la composición morfológica urbana, como se ha dicho. Se trata de un emplazamiento claramente elegido en las laderas de un valle relativamente angosto (el Valle de la Osa), que responde a una necesidad histórica de dominio y control territorial, por una parte, y de escondite defensivo, por otra, y que refleja una intención premeditada de ver sin ser vistos. Desde la atalaya del Cerro del Castillo al que se adosan los barrios primigenios de la localidad, se tiene un amplio control visual sobre el Valle del Guadalquivir, incluida la ciudad de Sevilla; pero a su vez, el núcleo urbano se esconde entre aquel cerro y Cerro Luna en un seguro refugio que permite la gestión del tránsito, a través de esta sierra, entre Extremadura y el Valle bético. Emplazamiento, historia y morfología urbana se combinan para dar lugar a un collage de segmentos paisajísticos diferenciados y adaptados al terreno, productos de la agregación de barrios levantados en diferentes momentos (figura 3).

La disposición encajada, estrecha y alargada se traslada a la estructura espacial del núcleo urbano y condiciona las pautas de crecimiento de la ciudad y su propia morfología y paisaje urbano interior. El origen del núcleo urbano actual se sitúa en el cerro del castillo, desde donde se dispone de una amplia visibilidad y control territorial, como se ha dicho. A sus pies se levanta en el siglo XII el primer barrio urbano de Constantina (La Morería), sobre la principal vía histórica de acceso a la población (el Camino Real, continuado hoy por la Calle Real). En la Baja Edad Media (siglo XV), coincidiendo con el cambio de una economía agraria y hortelana hacia otra ganadera y mesteña, la población vira hacia el Norte buscando el control de las rutas de la mesta y aproximándose a la Cañada Real del Robledo. Como resultado de ello surgen dos nuevos barrios separados por el curso del río: Las Cuestas, que se adosan a la Morería en la margen derecha; y San Sebastián (o el Tardón) levantado en un pequeño cerro situado en la margen izquierda.

En la Edad Moderna (siglos XV al XVIII) aquellos barrios originarios crecen hacia el sur y se acercan a la zona inundable, donde el río continúa ejerciendo de frontera física ciertamente más permeable debido a la apertura de siete puentes. La última zona de ocupación histórica es el propio cauce del río, que es entubado y soterrado en el siglo XIX, lo que permite la apertura de un eje urbano de dirección Sur-Norte; pero a pesar de su desaparición física del paisaje de la ciudad el río siguió actuando -y aún lo hace- como frontera psicológica y los habitantes de la Constantina actual continúan teniendo un marcado desconocimiento de los 


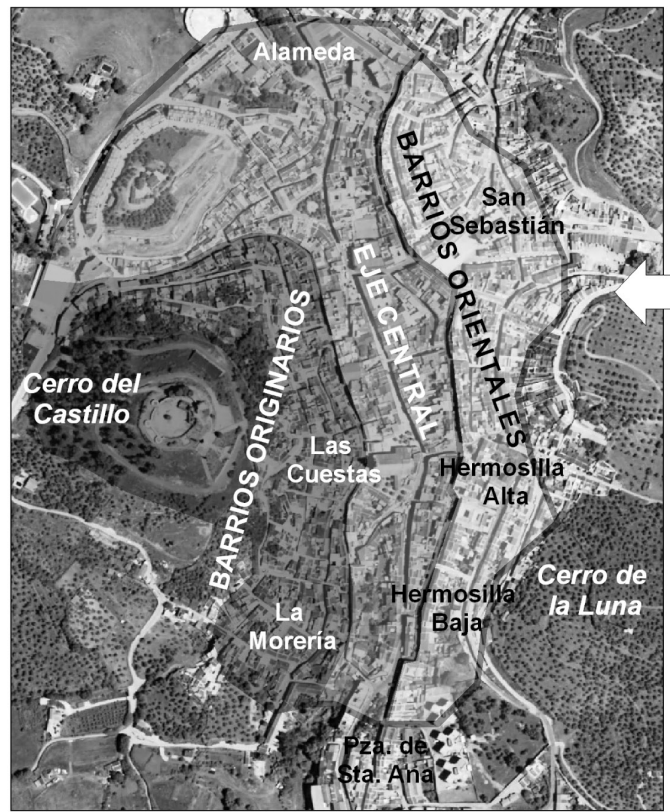

\section{ÁREAS PAISAJISTTICAS DE LA CIUDAD HISTÓRICA}

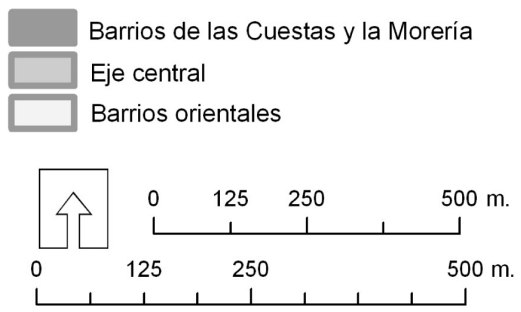

European Datum 1950, Proyección UTM 30 Norte

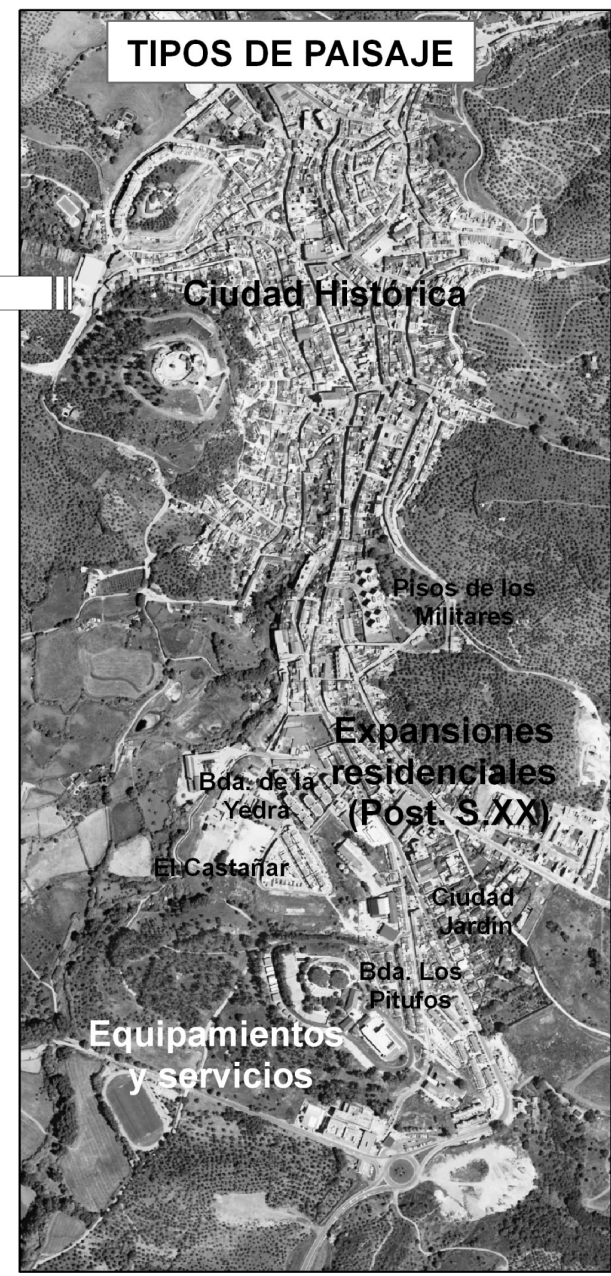

barrios de la otra ladera y, en particular, de los primigenios y más escarpados barrios de Las Cuestas y La Morería.

A finales del siglo XIX el conjunto histórico de Constantina está ya perfectamente dibujado, sobre todo en sus límites Oeste-Este, bien definidos -como hoy- por las laderas del Cerro del Castillo y Cerro Luna. En el siglo XX la expansión urbana se dirige sobre todo hacia el sur, buscando la conexión con la carretera de Lora del Río. Como colofón de aquella expansión se levanta en el sur de la localidad un área equipamientos y servicios públicos (colegios, albergue, gasolinera), a los que en los últimos años se añade un nuevo hospital comarcal.

Tales procesos de conformación histórico-urbanos han dado como resultado unas relaciones paradigmáticas entre estructuras morfológico-paisajísticas, especializaciones funcionales 
y segregaciones sociales, lo que otorga a los paisajes interiores de Constantina una elevada capacidad pedagógica para los estudios sobre la ciudad. En la ciudad histórica, tal como ésta quedó configurada en el siglo XIX, aún se reconocen sus tres áreas paisajísticas originarias:

- El área paisajística Las Morería-Las Cuestas, de barrios primigenios adosados al Cerro del Castillo, con calles estrechas que siguen las curvas de nivel, manzanas de pequeño tamaño irregularmente dispuestas y un paisaje de grano fino, con escasos espacios libres públicos. En términos funcionales su uso es exclusivamente residencial y desde una perspectiva social está habitada por población de extracción social humilde con una incipiente presencia de rehabilitadores urbanitas.

- $\quad$ El área paisajística eje central sigue un trazado lineal en sentido Norte-Sur sobre el antiguo cauce del río. Presenta un paisaje de grano más grueso debido al mayor tamaño de las parcelas que lo componen. En términos funcionales concentra tanto actividades especializadas (oficinas bancarias, dependencias administrativas, Ayuntamiento), como cotidianas (tiendas y bares) y usos residenciales (con una presencia importante de los grupos sociales más adinerados). Es, por tanto, un área de una elevada diversidad funcional y ello la convierte en el espacio de sociabilidad por antonomasia de Constantina.

- $\quad$ El área paisajística de los barrios orientales (Hermosilla Alta y Hermosilla Baja, San Sebastián, El Tardón...) presentan un callejero adaptado a las curvas de nivel de las distintas colinas que lo componen, un entramado urbano irregular y una cierta diversificación funcional y social.

La expansión urbana del siglo XX (hacia el sur y hacia el este) también responde a varios modelos, que se traducen en otras tantas áreas de paisaje:

- Un área de viviendas burguesas que responde al modelo de ciudad jardín situada entre la Avenida de Andalucía y el antiguo camino de Santa Catalina.

- Dos áreas diferenciadas de viviendas modestas: Una primera de callejero regular y pequeñas parcelas (barriadas de los Pitufos y el Castañar) y otra de bloques exentos de viviendas en altura (pisos de lo militares y barriada de la Yedra).

- Un área de equipamientos sobre la que se sustenta buena parte del papel de intermediación y las funciones urbanas de la Constantina actual. Presenta un paisaje de grano grueso y grandes parcelas, ocupada por el albergue público, diversos centros educativos y el hospital comarcal.

Si los paisajes son, sobre todo, miradas y representaciones, los elementos esenciales de los paisajes urbanos son las redes de espacios libres públicos desde donde se perciben, se disfrutan y se padecen las ciudades. Uno de los rasgos más distintivos del paisaje urbano de Constantina radica precisamente en la diversidad, la singularidad y la riqueza de sus espacios libres públicos, entre los que destacan los de la ciudad histórica, particularmente los situados en las áreas paisajísticas eje central y Las Cuestas-La Morería (Figura 4).

Los espacios libres públicos del Eje Central sobresalen por su diversidad, su accesibilidad, su equilibrada distribución en la trama urbana y, como consecuencia de todo ello, su elevada frecuentación. Sus plazas y jardines se estructuran de manera linealmente secuenciada desde la plaza de Santa Ana -situada en extremo Sur del conjunto histórico- y el paseo de la Alameda -ubicada en el Norte de la localidad-. Morfológicamente comprende espacios muy diferentes, entre los que se incluyen plazas y paseos con una vegetación destacada (plazas de Santa Ana y La Carretería y paseo de la Alameda), plazas de tipo salón de una gran armonía 
Figura 4

LOS ESPACIOS LIBRES PÚBLICOS

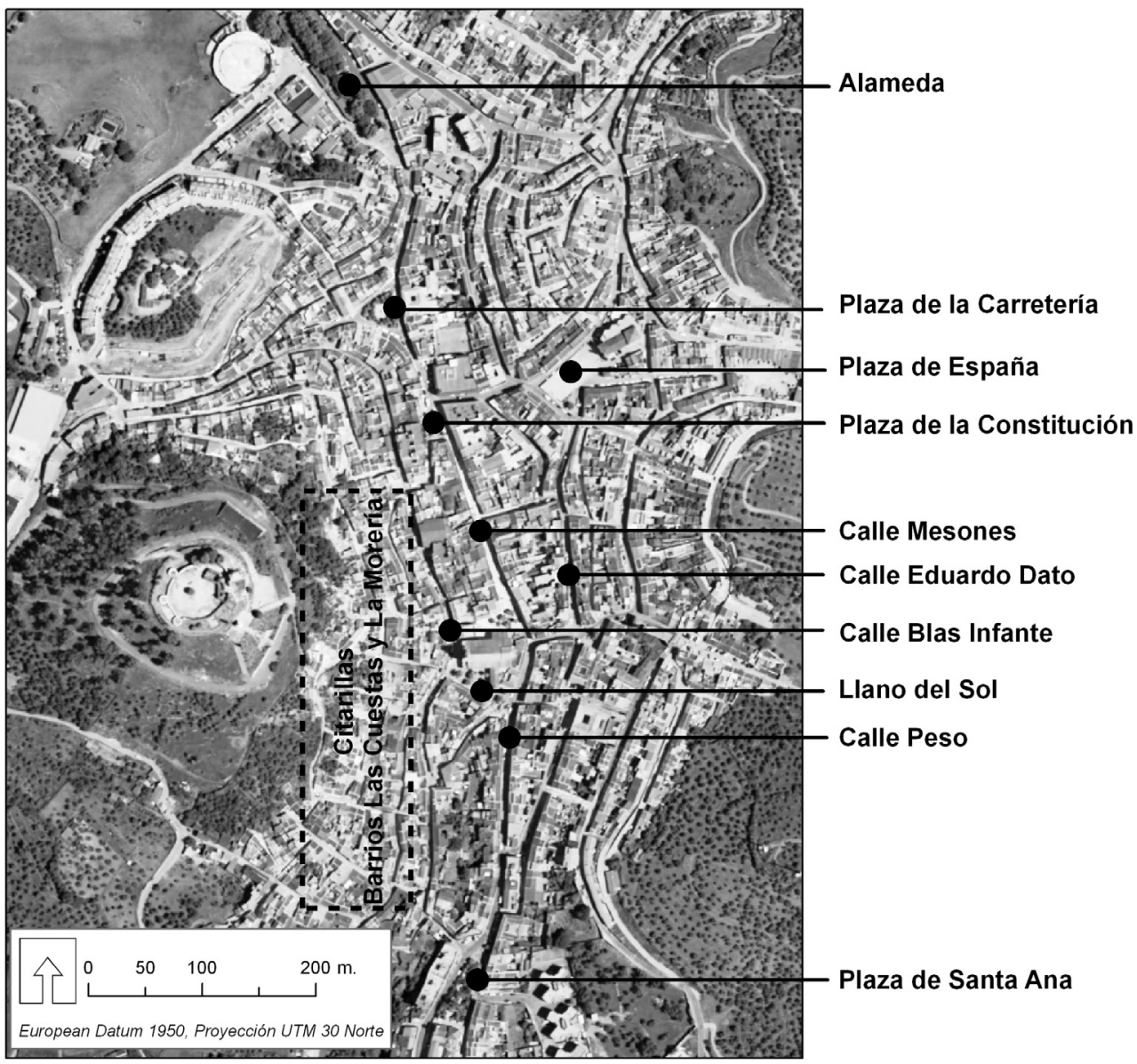

y calidad compositiva (Llano del Sol) y plazas duras escénicamente poco atractivas (plaza de la Constitución). Son todos ellos espacios relativamente bien dotados de mobiliario urbano entre los que destacan las fuentes públicas como hitos significativos y ejemplificativos de la relación de Constantina con el agua. Pero al margen de las fuentes como hitos significativos y estéticamente destacados se trata, en buena parte, de un mobiliario urbano estandarizado y disonante, lo que no siempre redunda en detrimento su utilización ciudadana. Así se pone de manifiesto en la plaza de la Constitución, dotada de un mobiliario infantil estandarizado que a la par que banaliza el escenario urbano anima a la concurrencia ciudadana consiguiendo amortiguar la dureza compositiva de este pequeño enclave.

Los ejes viarios de este eje central presentan una clara jerarquización con calles largas, relativamente rectas y allanadas (abiertas sobre el antiguo cauce del río), atravesadas por otras cortas y desniveladas que se adaptan al relieve encajado. Entre las vías principales 
sobresalen las calles Peso, Mesones, Eduardo Dato y Blas Infante. Sus frentes de parcela destacan por la presencia de palacetes y viviendas de cierto empaque -como corresponde a un área predominantemente burguesa- entre las que sobresalen las fachadas de corte modernista de la Plaza de Santa Ana atribuidas a la escuela de Aníbal González. Son vías particularmente transitadas y utilizadas, en particular la calle Mesones cuyo carácter peatonal la convierte en el espacio de sociabilidad por antonomasia de Constantina. Sobre ellas se desarrollan los principales itinerarios festivos de la localidad (procesiones de Semana Santa, cabalgata de Reyes Magos, procesión de Virgen del Robledo); lo que, conjuntamente con la accesibilidad y llaneza de las vías principales, anima a la frecuentación ciudadana y confiere a esta parte de la ciudad un fuerte arraigo; pero, a su vez, son ejes muy congestionados por el trazado de la travesía urbana de la A-455 y ello les resta confortabilidad.

Otra de las redes destacadas de espacios libres públicos de Constantina es la del área de Las Cuestas-La Morería. Es ésta un área poco frecuentada por los vecinos no residentes debido a su uso exclusivamente residencial, a su marcada segregación social y a su propia dificultad topográfica. El rasgo más distintivo de sus espacios libres públicos es el carácter pintoresco de sus calles estrechas, irregulares y desniveladas, con múltiples escaleras a las que se abren viviendas modestas generalmente de una sola planta y con elevados valores de conjunto. Aquí las plazas se reducen a pequeños rincones que salvan los desniveles entre el viario y las viviendas (las denominadas citarillas), donde el espacio público se confunde con el privado en enclaves cuidados y mimados por los vecinos que singularizan esta parte de la ciudad y la dotan de un gran atractivo escénico.

La potencia, la diversidad y la singularidad paisajística de las redes de espacios públicos del eje central y del área de las Cuestas-La Morería eclipsan, en cierta medida, los espacios públicos de las restantes piezas urbanas, menos frecuentados por la población, a excepción de la Plaza de España, abierta en la segunda mitad del siglo XX en el barrio de San Sebastián para albergar en su sótano el mercado municipal de abastos. Ello le otorga un carácter de una plaza dura, escénicamente poco atractiva, pero con frentes de parcela muy potentes entre los que destacan la portada de la antigua iglesia de la Concepción y viviendas burguesas de cierto empaque.

Uno de los rasgos más distintivos del paisaje urbano de Constantina reside, en suma, en la singularidad, la diversidad y riqueza de sus espacios libres públicos, en particular de los situados en concurrido Eje Central y en los pintorescos barrios de Las Cuestas-La Morería. Ambos traslucen el emplazamiento encajado de la ciudad y su topografía urbana accidentada, reflejada en el belvedere paisajístico de Las Cuestas-La Moreria y en el punto focal y de confluencias de miradas de los espacios libres públicos del Eje Central.

\section{ALGUNAS CONCLUSIONES}

El conocimiento científico del paisaje no ha abordado de manera suficiente las relaciones entre la ciudad y sus paisajes y se carece de un marco epistemológico organizado, unitario y coherente para el estudio de los paisajes urbanos. Es éste un vacío inasumible desde la perspectiva actual del paisaje, considerado éste -como hace el Convenio Europeo-, como una confluencia de miradas y representaciones, como un catalizador de la calidad de vida de las poblaciones y como un recurso básico para el desarrollo de las ciudades y los territorios. 
Este artículo pretende contribuir a la superación de ese vacío a través de una propuesta metodológica para la caracterización de paisajes urbanos en ciudades pequeñas y medias. Como hipótesis de trabajo se mantiene que en tales ciudades los paisajes urbanos interiores están indisolublemente ligados a los de sus contornos territoriales. Ello obliga a una aproximación multiescalar que imbrique unos paisajes en otros y contribuya a la lectura de los paisajes desde la ciudad y a la interpretación de ésta a través de sus paisajes. Tal lectura se plantea aquí a partir de tres escalas básicas: 1) La escala territorial, considerando el territorio en un sentido amplio como soporte físico-natural, espacio geográfico-relacional y contexto económico-cultural; 2) Las periferias inmediatas de las ciudades o escala de interfaces urbano-rurales; y 3) La escala urbana propiamente dicha o ciudad compacta mediterránea. Esta última es, en sí misma, una escala compleja, que tiene por infraestructura básica el entramado urbano y cuya quintaesencia paisajística son las redes de espacios libres públicos.

Para ilustrar la propuesta metodológica se ha recurrido a una pequeña ciudad de Sierra Morena (Constantina) cuyo elevado valor patrimonial y paisajístico queda avalado por la inclusión de su término municipal en el Parque Natural de la Sierra Norte de Sevilla y en la Reserva de la Biosfera Dehesas de Sierra Morena, así como por la catalogación de su Conjunto Histórico Bien de Interés Cultural. En términos socio-económicos se trata de una ciudad asolada por el abandono y el despoblamiento desarrollista, redescubierta por la sociedad del ocio y ensalzada por el ambientalismo y el patrimonialismo actual. Como consecuencia de ello sus paisajes ofrecen un ejemplo de alianzas paradigmáticas entre quiebra económica desarrollista-preservación del tejido urbano interior, por una parte, y declaración de Parque Natural-alejamiento del modelo de ciudad difusa, por otra. Junto con la singularidad de su emplazamiento encajado, ello se trasluce en la sencillez, las armonías compositivas y la singularidad de sus paisajes urbanos y periurbanos, marcados por el agua y el relieve y modelados por la historia y el entorno territorial en que se insertan.

La marginación socio-económica desarrollista de Constantina y, posteriormente, la escasa afección del devorador modelo territorial de ciudad difusa se ha traducido, en sus paisajes de interfaces urbano-rurales, en una particular y paradójica combinación entre abandono y preservación morfológico-paisajística. A pesar de la degradación asociada a la despoblación y el abandono sus paisajes mantienen elevados valores entre los que destacan la nitidez de los bordes campo-ciudad, las armonías compositivas y la adaptación a la topografía. Como áreas de interés paisajísticos en los alrededores de la ciudad sobresalen el área de antiguas huertas de la Yedra y el paraje forestal de El Robledo, que a modo de herencia histórica compendian el devenir de una población originariamente agrícola y hortelana y más tarde ganadera y mesteña. En términos prospectivos son dos parajes sometidos a dinámicas muy diferentes, de degradación y amenazas edificatorias el primero y de enaltecimiento y poca presión urbana el segundo, debido a su lejanía la ciudad y al simbolismo que le confiere la presencia de la ermita de la patrona (la virgen del Robledo).

El estudio paisajístico de Constantina ha puesto de manifiesto que en ciudades pequeñas y medidas donde la simbiosis urbano-rural es antigua e intensa los paisajes urbanos interiores no se explican sin los de sus entornos agro-rurales; y que tanto unos como otros encuentran su razón de ser en el contexto territorial en el que se insertan. Se trata, en todas las escalas consideradas, de unos paisajes con elevados valores y potencialidades escénicas; en el caso de los paisajes urbanos interiores, poseen, además, una gran capacidad pedagógica para ilus- 
trar las dinámicas históricas de ocupación del espacio y las relaciones, siempre complejas, entre morfologías y paisajes urbanos, especializaciones funcionales y segregaciones sociales.

Uno de los rasgos más distintivos del paisaje urbano de Constantina radica precisamente en la singularidad, la diversidad y la riqueza de sus espacios libres públicos, estructurada en redes diferenciadas entre las que destaca la secuenciación de espacios públicos del eje central y el carácter pintoresco de los espacios libres públicos de Las Cuestas-La Morería. Si los paisajes son, esencialmente, miradas y representaciones, los atributos esenciales de los espacios libres públicos de Constantina son la confortabilidad, la accesibilidad y la frecuentación, en el caso de los espacios libres públicos del eje central, y el carácter pintoresco y la atalaya paisajística que ofrecen los espacios libres públicos de Las Cuestas-La Morería.

También se ha puesto de manifiesto la capacidad prospectiva del análisis del paisaje para anticipar las áreas de oportunidad, tanto en el interior de la ciudad como en los paisajes de interfaces urbano-rurales, que en el caso de Constantina se asocian fundamentalmente al proyecto de carretera de circunvalación y a la liberación del eje ocupado por la travesía urbana de la A-455. E igualmente se ha podido comprobar el papel crucial que tienen los paisajes urbanos y periurbanos como escenarios de uso y disfrute ciudadano, especialmente en el contexto catastral de Sierra Morena de predominio de grandes fincas privadas agro-ganaderas donde el disfrute de los paisajes y las visitas al Parque Natural necesariamente se circunscriben a los pueblos y sus alrededores.

La disposición morfológica urbana de Constantina condicionada por el emplazamiento encajado, junto con las particularidades funcionales y sociales de las distintas piezas urbanas, confiere una gran legibilidad y capacidad pedagógica a sus paisajes urbanos interiores. El estudio paisajístico de la ciudad, a través de sus diferentes tipos y áreas de paisajes, se erige pues en un escenario privilegiado para abundar en las relaciones, siempre complejas, entre morfología y paisajes urbanos, especializaciones funcionales y segregaciones sociales. Se pone así de manifiesto la virtualidad que tienen los paisajes urbanos para el estudio general de la ciudad y para la contextualización de ésta en marcos territoriales más amplios.

\section{BIBLIOGRAFÍA}

ALBERDI COLLANTES, J.C. (2002). «La ciudad elimina la función agraria en su proximidad: el ejemplo de San Sebastián», Anales de Geografía de la Universidad Complutense, $\mathrm{n}^{\circ} 22$, pp. 189-217.

BADIA, A., ESTANY, G., OTERO, I. y BOADA, M. (2010): «Estudio del crecimiento urbano disperso y los cambios en el paisaje de Matadepera (Región Metropolitana de Barcelona)», Boletín de la Asociación de Geógrafos Españoles, nº 54, pp. 301-322.

BATLLE, E. (2006): «El sistema de espacios libres urbanos», en MATA, R. Y TORROJA, A. (Coords.): El paisaje y la gestión del territorio. Criterios paisajísticos en la ordenación del territorio y el urbanismo. Barcelona, Diputación de Barcelona, pp. 103-112.

BRANDIS, M.D. (2008): «La imagen cultural y turística de las ciudades españolas patrimonio mundial», en TROITIÑO, M.A. (Coord.): Ciudades Patrimonio de la Humanidad. Patrimonio, turismo y recuperación urbana. Sevilla, Consejería de Cultura (Junta de Andalucía)-Universidad Internacional de Andalucía, pp. 70-97.

CAPEL, H. (2002): La morfología de las ciudades. Barcelona, Ediciones del Serbal. 
CARRERA DÍAZ, G. (2006): «Itinerarios y rutas: Herramientas para la documentación y puesta en valor del patrimonio cultural», en IAPH. Boletín del Instituto Andaluz de Patrimonio Histórico, $\mathrm{n}^{\circ}$ 60, pp. 52-69.

CASTILLO, J. (2009): «La dimensión territorial del patrimonio histórico». En CASTILLO, J. et al. Patrimonio histórico y desarrollo territorial. Sevilla, Universidad Internacional de Andalucía, pp. 26-71.

COLLANTES DE TERÁN, A. (2011): «Constantina medieval en el Archivo Municipal de Sevilla», en VALOR PIECHOTTA, M. (Coord.) Historia y arqueología de la Constantina medieval. Sevilla, Secretariado de Publicaciones de la Universidad de Sevilla, pp. 35-49.

COMISIÓN EUROPEA (2010): Europa 2020. Una estrategia para un crecimiento inteligente, sostenible e integrador. Bruselas, Comunicación de la Comisión Europea COM (2010)2020.

CONSEJERÍA DE OBRAS PÚBLICAS Y TRANSPORTE Y CONSEJERÍA DE MEDIO AMBIENTE (2005) «Mapa de los paisajes de Andalucía», en Atlas de Andalucía Tomo II. Sevilla (www.paisajeyterritorio.es).

CONSEJO DE EUROPA (2000) Convenio Europeo del Paisaje. Florencia, Consejo de Europa.

CORTINA, A. (2008): «La dimensión económica del paisaje», en BUSQUETS, J. Y CORTINA, A. (Coords.): Gestión del paisaje. Manual de protección, gestión y ordenación del paisaje. Barcelona, Ariel, pp. 274.

COSGROVE, D. (2002): «Observando la naturaleza: el paisaje y el sentido europeo de la vista», Boletín de la Asociación de Geógrafos Españoles, nº 34, pp. 63-89.

COUNTRYSIDE AGENCY AND SCOTTISH NATURAL HERITAJE (2002): Landscape Character Assessment: England and Scotland. Wetherby, Countryside Agency an Scottish Natural Heritage.

FERNÁNDEZ, M. y TATJER, M. (2008): «La interpretación del paisaje urbano», en BUSQUETS, J. y CORTINA, A. (Coords.): Gestión del paisaje. Manual de protección, gestión y ordenación del paisaje. Barcelona, Ariel, pp. 221-238.

FERRER AIXALÀ, A. (2008): «Paisajes urbanos», en BUSQUETS, J. Y CORTINA, A. (coords.): Gestión del paisaje. Manual de protección, gestión y ordenación del paisaje. Barcelona, Ariel, pp. 41-59.

GARCÍA GARCÍA, A. (2011): «El valor de la perspectiva geográfica para el análisis de los espacios públicos urbanos», Boletín de la Asociación de Geógrafos Españoles, $\mathrm{n}^{\circ}$ 55, pp. 281-301.

JUNTA DE ANDALUCÍA (2012): Estrategia del Paisaje de Andalucía. Sevilla, Junta de Andalucía.

LINARES GÓMEZ DEL PULGAR, I. y TEJEDOR CABRERA, A. (2001): «Proyectos y reformas urbanas en Constantina en los siglos XIX y XX», en Laboratorio de Arte $\mathrm{n}^{\circ} 14$, pp. 65-86.

MADERUELO, J. (2005): El paisaje. Génesis de un concepto. Madrid, Ed. Abada.

MARTÍN-VIVALDI CABALLERO, M.E. y JIMÉNEZ OLIVENCIA, Y. (1994): «Transformación del paisaje en el área de influencia de la capital granadina: La Vega de Granada», Cuadernos Geográficos, no 22-23, pp. 175-193. 
MARTÍNEZ SARANDESES, J. (2002): «El valor paisajístico de los espacios libres urbanos», en ZOIDO, F. Y VENEGAS, C. (Coord.): Paisaje y ordenación del territorio. Sevilla, Consejería de Obras Públicas y Transporte y Fundación Duques de Soria.

MATA, R. (2008): «El paisaje, patrimonio y recurso para el desarrollo territorial sostenible; conocimiento y acción pública», Arbor: Ciencia, Pensamiento y Cultura, CLXXXIV, n ${ }^{\circ}$ 729, pp. 155-172.

MATA, R. y SANZ HERRÁIZ, C. (Dirs.) (2003): Atlas de los paisajes de España. Madrid, Ministerio de Medio Ambiente.

MATÍAS, M. (2011): «La integración paisajística y sus fundamentos. Metodología para la integración para construcciones dispersas en el medio rural», Boletín de la Asociación de Geógrafos Españoles, no 56, pp. 225-243.

OCAÑA OCAÑA, C. y GÓMEZ MORENO, M. L. (2003). Las vistas como recurso territorial. Ensayo de evaluación del paisaje visual mediante SIG. Málaga, Departamento de Geografía, Universidad de Málaga.

OJEDA RIVERA, J.F. y SILVA PÉREZ, R. (2002) «Aproximación a los paisajes de la Sierra Morena andaluza», en Paisajes y Ordenación del Territorio. Sevilla, Fundación Duques de Soria-Consejería de Obras Públicas y Transporte, Junta de Andalucía, pp. 71-91.

PARDO GARCÍA, S. (2010): «Aproximación metodológica a las vistas de los núcleos de población: el caso de Vélez Málaga», en Cuadernos Geográficos nº 46, pp. 35-63.

PEDRAZZINI, L. (Coord.) (2011): Ámbitos periurbanos. Líneas guía paisajísticas para la gobernanza del territorio. RegioneLombardia. PaysMedUrban.

PINO, J., RODÀ, F. y GUIRADO, M. (2006): «Ecología del paisaje y gestión de la matrices de espacios abiertos», en MATA, R. y TORROJA, A. (Coords.): El paisaje y la gestión del territorio. Criterios paisajísticos en la ordenación del territorio y el urbanismo. Barcelona, Diputación de Barcelona, pp. 61-78.

QUIRÓS LINARES, F. (2004): «El paisaje urbano en la Geografía española moderna», en ORTEGA CANTERO, N. (Ed.): Naturaleza y cultura del paisaje. Madrid, Fundación Duques de Soria y Universidad Autónoma de Madrid.

RULLAN SALAMANCA, O. (2012): «Urbanismo expansivo en el Estado español: de la utopía a la realidad», en GOZÁLVEZ, V. y MARCO, J.A. (Eds.): Geografía, retos ambientales y territoriales, Alicante, Asociación de Geógrafos Españoles, pp. 165-211.

SÁNCHEZ DEL ÁRBOL, A. y MEDINA BARBERO, R. (2008): Bases metodológicas y criterios operativos de carácter paisajístico en la relación carretera-núcleos urbanos de pequeño y mediano tamaño. Ejemplificación en la comarca del Valle de Lecrín. Sevilla, Consejería de Obras Públicas y Transporte. Junta de Andalucía.

SCAZZOSI, L. (2006): «<<Valorar >> los paisajes», en MATA, R. y TORROJA, A. (Coords.): El paisaje y la gestión del territorio. Criterios paisajísticos en la ordenación del territorio y el urbanismo. Barcelona, Diputación de Barcelona, pp. 267-302.

SILVA PÉREZ, R. y OJEDA RIVERA, J.F. (2001) «La sierra morena sevillana. A la sombra de la urbe y el mercado», Ería, no 55 , pp. 255-275.

TROITIÑO, M.A. (1992): Cascos antiguos y centros históricos: problemas, políticas y dinámicas urbanas. Madrid, Ministerio de Obras Públicas y Transportes. 
VALOR, M., HENARES, T. y LAFUENTE, P. (2006): «El entorno del castillo: Primeros resultados de una aproximación al paisaje histórico de Constantina», en Anuario Arqueológico de Andalucía. Sevilla, Consejería de Cultura-Junta de Andalucía.

VENEGAS MORENO, C. y RODRÍGUEZ RODRÍGUEZ, J. (2002): «Valoración de los paisajes monumentales. Una propuesta metodológica para la integración paisajística de los conjuntos históricos», en VENEGAS, C., Y ZOIDO, F. (Coord.) Paisaje y Ordenación del Territorio. Sevilla, Consejería de Obras Públicas y Transportes Junta de Andalucía, pp. 153-165.

ZÁRATE MARTÍN, M.A. (2007): «Toledo. Planeamiento y especulación en ciudades históricas», Anales de Geografía vol. 27 n 2, pp. 151-175.

ZARATE MARTÍN, M.A (2011): «Paisajes culturales urbanos. Entre la protección y la destrucción», Boletín de la Asociación de Geógrafos Españoles n 57, pp. 17-194.

ZOIDO NARANJO, F. (2012): «Paisaje urbano. Aportaciones para la definición de un marco teórico, conceptual y metodológico», en DELGADO, C., JUARISTI, J. y TOMÉ, S. Ciudades y paisajes urbanos en el siglo XXI. Santander, Ediciones Librería Estudio, pp. 13-91. 
